\title{
Association of Maternal Zinc Status and Fetal Outcome
}

\author{
Rahman $\mathrm{MH}^{1}$, Hoque $\mathrm{M}^{2}$, Jahan $\mathrm{WA}^{3}$, Hassan $\mathrm{Z}^{4}$, Shakoor MA ${ }^{5}$, Begum $\mathrm{BA}^{6}$, Sultan MK
}

\begin{abstract}
Background: Maternal zinc is related to the growth and development of newborn babies. Low birth weight babies leads to higher infant mortality rate \& unfortunately the incidence of LBW is higher in Bangladesh. Objective: The present study has been undertaken to evaluate the zinc status in mothers with normal and low birth weight as well as to find-out the association between maternal zinc level and birth weight of babies in a selected hospital in Dhaka city. Methods: This case-control study on 20 non-pregnant and 40 pregnant women was done to find out the relationship between maternal zinc status and fetal outcome. This study was carried out in the department of Biochemistry, Dhaka Medical College, Dhaka, in collaboration with Bangladesh Atomic Energy Center, Dhaka from the period of July 2003 to June 2004. Result: The mean age (yrs), height (cms) \& parity (number) in Group-A found to be $23.7 \pm 4.8,154 \pm 7$ and $1.82 \pm 0.85$ respectively \& those in Group-B were $24.5 \pm 4.3,153 \pm 9$ and $1.86 \pm 0.89$ respectively without any significant difference between the groups. The mean plasma zinc concentrations in Control \& Cases were $90.10 \pm 13.96$ and $64.54 \pm 16.22 \mu \mathrm{g} / \mathrm{dl}$ respectively. The mean plasma zinc concentrations in Subgroup B-I \& B-II were $63.85 \pm 12.49$ and $65.18 \pm$ $18.48 \mu \mathrm{g} / \mathrm{dl}$ respectively. Conclusion: Maternal zinc status is not associated with fetal outcomes. [J Shaheed Suhrawardy Med Coll, 2013;5(2): 7-10]
\end{abstract}

Keywords: Zinc, pregnancy, fetal outcome, zinc status, fetal growth, birth weight, babies

Received: January 2014; Revised: March 2014; Accepted: April 2014

\section{Introduction}

Zinc is an essential nutrient required for normal growth and development ${ }^{1}$. The requirement of zinc increases in pregnancy and adverse effects of zinc deficiency during gestation have been documented in animal study ${ }^{2}$. Zinc is important for healthy pregnancy outcome ${ }^{3}$. Maternal zinc deficiency can cause infertility, prolonged labor, intrauterine growth retardation, teratogenesis and embryonic or fetal death $^{4-5}$. Numerous reports ${ }^{6-8}$ have been published depicting the association of zinc deficiency with cessation of growth, impairment of taste acuity, anorexia and reduced appetite, protein energy malnutrition, dermatitis, hypogonadism with suppression of both primary and secondary sexual characteristics, diarrhoea and intestinal mucosal abnormality, cirrhosis of liver, defective bone formation, increased erythrocyte fragility and depressed cellular $\mathrm{Na}+-$ $\mathrm{K}+$ pump activity.

Low birth weight infants $(<2500 \mathrm{gm})$ remain a major public health problem in many parts of the world and are associated with short- and long-term adverse consequences ${ }^{3-4}$. Maternal nutritional status is claimed to be closely associated with the birth weight of their newborn babies ${ }^{5}$. Study of maternal zinc status in pregnancy may be helpful in understanding their role in fetal outcome. If the maternal zinc deficiency been identified as an important contributing factor of poor fetal growth then zinc supplementation during pregnancy could be advocated to reduce the incidence of low birth weight babies $\&$ neonatal or infant mortality rate. Thus, the adverse effects of zinc deficiency might begin before birth ${ }^{6}$. Infants born to

1. Dr. Md. Habibur Rahman, Assistant Professor, Department of Biochemistry, Shaheed Suhrawardy Medical College, Dhaka

2. Prof. Dr. Mozammel Hoque, Professor, Department of Biochemistry, Bangabandhu Sheikh Mujib Medical University, Dhaka

3. Dr. Waseka Akhter Jahan, Assistant Professor, Department of Biochemistry, National Institute of Neurosciences \& Hospital, Dhaka

4. Prof. Dr. Zaheed Hassan, Professor, Department of Physiology, Bangladesh University of Health Science, Dhaka

5. Dr. M A Shakoor, Associate Professor, Department of Physical Medicine \& Rehabilitation, Bangabandhu Sheikh Mujib Medical University, Dhaka

6. Dr. Bilqis Ara Begum, Associate Professor, Department of Biochemistry, Dhaka Medical College, Dhaka

7. Dr. Md. Kamal Sultan, Assistant Professor, Department of Biochemistry, Shaheed Suhrawardy Medical College, Dhaka

\section{Correspondence}

Dr. Md. Habibur Rahman, Assistant Professor, Department of Biochemistry, Shaheed Suhrawardy Medical College, Sher-E-Bangla Nagar, Dhaka, Bangladesh; Cell No.: +8801715563062; Email: mhrahman65@gmail.com

Conflict of interest: None

Financial Support: None

Contributions by authors: MHR, MH, ZH, \& MKs,-Protocol development to manuscript writing. WAJ, MAS,-revised the manuscript. 
zinc-supplemented women weighted $126 \mathrm{~g}$ more at birth, were $0.6 \mathrm{~cm}$ longer and had $0.4 \mathrm{~cm}$ greater head circumference than infants born to mothers receiving the placebo ${ }^{7}$. However, zinc is $99 \%$ protein bound in plasma, its levels fluctuate widely with stress, and plasma zinc represents less than $1 \%$ of the total body $\mathrm{pool}^{8}$. Therefore the present study was designed to make-out the association of maternal zinc status and fetal outcome in Bangladeshi pregnant women.

\section{Methodology}

This case-control study was done on 20 non-pregnant and 40 pregnant women was done to find out the relationship between maternal zinc status and fetal outcome. This study was carried out in the department of Biochemistry, Dhaka Medical College, Dhaka, in collaboration with Bangladesh Atomic Energy Center, Dhaka from the period of July 2003 to June 2004. Age matched women (120 in number) of reproductive age between 18 to 45 years was primarily selected as sample. Among them, 20 non-pregnant and 100 pregnant women attending and admitted in the department of Obstetrics and Gynecology Dhaka Medical College Hospital \& Azimpur Maternity and Child Health Institute, Dhaka was preliminary selected. There were two groups named as group A (Control) containing 20 non-pregnant women and group B (Cases) containing 40 pregnant women; again group B was divided into two subgroups of Cases into subgroup B-I which had 20 pregnant women giving birth to normal birth weight (?2500g) babies and subgroup B-II which had 20 pregnant women giving birth to low birth weight $(<2500 \mathrm{~g})$ babies. Women with regular menstrual cycles, at least for 3 months before conception, no use of oral contraceptive pill in at least for 3 months before conception, live-born neonates, no known anomaly, perinatally or postnatally and no family history of dwarfism were included in this study. Multiple gestation, complicated pregnancy, diabetes or chronic hypertension in mothers, patient's sufferings from malnutrition and anemia as well as alcohol users and smokers and drug abusers were excluded from this study. From all the selected subjects, $5 \mathrm{ml}$ fasting venous blood was collected by disposable syringe with full aseptic precaution from all study subjects; which in pregnant women were done before the time of delivery. Collected blood was immediately transferred to dry, clean, zinc-free plastic polypropylene test tubes containing anticoagulant (sodium heparin $20 \mu \mathrm{l}$ ). About 112 blood samples were collected. After that, 20 blood samples of the pregnant women who delivered NBW babies and 20 blood samples of the pregnant women who delivered LBW babies were finally selected for the study and 20 blood samples of the non-pregnant women were collected as control samples. The test tubes were closed by zinc free caps \& inverted several times for properly mixing the blood with anti-coagulant. The tubes containing blood were kept at room temperature for 20 minutes, then centrifuged for 10 minutes at $3500 \mathrm{rpm}$. Plasma was picked up without disturbing the buffy coat using micropipette tip and transferred into zinc-free polypropylene tubes. The plasma was immediately stored at $-56^{\circ} \mathrm{C}$ until analysis. After removing the plasma the buffy coat at the top of the cells were carefully removed $\&$ the cells (RBC) were washed three times with ice-cold normal saline. Then $1.0 \mathrm{ml}$ of washed cell was added to $1.0 \mathrm{ml}$ of de-ionized distilled water in a polypropylene tube; mixed well in a vortex mixer and the cells were lysed by freezing and stored at $-56^{\circ} \mathrm{C}$ until analysis. Data regarding age, height and parity in all study subjects \& the gestational age in cases only were recorded properly. Birth weight, crownheel length and head circumferences were measured in all newborns between 12-24 hours after birth, following resolution of edema. Birth weight was measured by a leverweighing machine. Crown-heel length was measured by suspending the baby by the ankles ${ }^{8-10}$ and then taking measurement by an oilcloth tailor's tape. Head circumference was measured at the largest occipito-frontal circumference $^{11}$. Rohrer's ponderal index (PI) was calculated by using the formula ${ }^{12}$. MS Excel and SPSS software were used to analyze the data. Unpaired t-test and r-test (correlation coefficient test) were done to see the level of significance. $\mathrm{P}<0.05$ was taken as the level of significance.

\section{Results}

The mean age (yrs), height (cms) \& parity (number) in Group-A found to be $23.7 \pm 4.8,154 \pm 7$ and $1.82 \pm 0.85$ respectively \& those in Group-B were $24.5 \pm 4.3,153 \pm 9$ and $1.86 \pm 0.89$ respectively without any significant difference between the groups (Table -I).

Table-I: Comparison of anthropometric and clinical data between control (Group - A) and cases (Group - B)

\begin{tabular}{lccc}
\hline Parameter & $\begin{array}{c}\text { Group- A } \\
(\mathrm{n}=20)\end{array}$ & $\begin{array}{c}\text { Group- B } \\
(\mathrm{n}=40)\end{array}$ & $\begin{array}{c}\text { Level of } \\
\text { significance (p) }\end{array}$ \\
\hline Age (yrs) & $23.7 \pm 4.8$ & $23.5 \pm 4.3$ & $\mathrm{NS}$ \\
Height (cms) & $154 \pm 7$ & $153 \pm 9$ & $\mathrm{NS}$ \\
Parity (number) & $1.82 \pm 0.85$ & $1.86 \pm 0.89$ & $\mathrm{NS}$
\end{tabular}

*NS: Not significant; Values are expressed in Mean \pm SD

The mean age (yrs), height (cms), gestational age (wks) \& parity (number) in Subgroup B-1 found to be $23.5 \pm 4.4$, $153 \pm 5,40.06 \pm 1.26$ and $1.84 \pm 0.63$ respectively $\&$ those in Subgroup B-2 were 24.2 $\pm 4.3,152 \pm 7,40.02 \pm 1.21$ and $1.88 \pm 0.59$ respectively without any significant difference between the Subgroups.

Table-2: Comparison of anthropometric and clinical data between subgroup of cases $($ Mean $\pm \mathrm{SD})$

\begin{tabular}{lccc}
\hline Parameter & $\begin{array}{c}\text { Group A } \\
(\mathrm{n}=20)\end{array}$ & $\begin{array}{c}\text { Subgroup B1 } \\
(\mathrm{n}=20)\end{array}$ & $\begin{array}{c}\text { Subgroup B2 } \\
(\mathrm{n}=20)\end{array}$ \\
\hline Age (yrs) & $23.7 \pm 4.8$ & $23.5 \pm 4.4$ & $24.2 \pm 4.3$ \\
Height (cms) & $154 \pm 7$ & $153 \pm 5$ & $152 \pm 7$ \\
Gestational age (wks) & 0 & $40.06 \pm 1.26$ & $40.02 \pm 1.21$ \\
Parity (number) & $1.82 \pm 0.85$ & $1.84 \pm 0.63$ & $1.88 \pm 0.59$ \\
\hline
\end{tabular}


The mean birth weight $(\mathrm{g})$, crown-heel length (cms), headcircumference (cms) and ponderal index in Subgroup B-1 found to be $2892 \pm 166,49.4 \pm 1.8,35.7 \pm 0.6$ and $2.49 \pm$ $0.23 \&$ those in Subgroup B-2 were $2037 \pm 168,45.3 \pm 2.6$, $32.8 \pm 0.9$ and $2.38 \pm 0.27$ respectively (Table -3 ). All the anthropometrical measurements found significantly higher in babies of Subgroup B-1 compared to Subgroup B-2.

Table-3: Comparison of anthropometric data between babies of cases subgroup (Mean $\pm \mathrm{SD})$

\begin{tabular}{lccc}
\hline $\begin{array}{l}\text { Anthropometric } \\
\text { Parameter }\end{array}$ & $\begin{array}{c}\text { Subgroup B1 } \\
(\mathbf{n}=\mathbf{2 0})\end{array}$ & $\begin{array}{c}\text { Subgroup B2 } \\
\mathbf{( n = 2 0 )}\end{array}$ & $\begin{array}{c}\text { Level of } \\
\text { significance(p) }\end{array}$ \\
\hline Birth weight of babies (g) & $2892 \pm 166$ & $2037 \pm 168$ & $<0.05$ \\
Crown-heel length (cms) & $49.4 \pm 1.8$ & $45.3 \pm 2.6$ & $<0.05$ \\
Head circumference (cms) & $35.7 \pm 0.6$ & $32.8 \pm 0.9$ & $<0.05$ \\
Ponderal index (PI) & $2.49 \pm 0.23$ & $2.38 \pm 0.27$ & $<0.05$
\end{tabular}

* Significant; ** P1 = weight - length ratios of newborn babies.

The mean plasma zinc concentrations in Control \& Cases were $90.10 \pm 13.96$ and $64.54 \pm 16.22 \mu \mathrm{g} / \mathrm{dl}$ respectively. Plasma zinc concentrations found significantly higher in Group-A than in Group-B. The mean RBC zinc concentration in Group-A \& Group-B were $66.92 \pm 12.74$ and $68.85 \pm 16.82 \mu \mathrm{g} / \mathrm{g} \mathrm{Hb}$ respectively, without any significant difference between the groups.

Table-4: Comparison of plasma and RBC Zinc concentrations between control (Group - A) and cases (Group - B).

\begin{tabular}{lccc}
\hline \multicolumn{1}{c}{ Zinc levels } & $\begin{array}{c}\text { Group A } \\
\text { Mean } \pm \text { SD }\end{array}$ & $\begin{array}{c}\text { Subgroup B1 } \\
\text { Mean } \pm \text { SD }\end{array}$ & $p$ \\
\hline Plasma $(\mu \mathrm{g} / \mathrm{dl})$ & $90.10 \pm 13.96$ & $63.85 \pm 12.49$ & $<0.05$ \\
RBC $(\mu \mathrm{g} / \mathrm{dl})$ & $66.92 \pm 12.74$ & $70.62 \pm 16.71$ & $0.05(\mathrm{NS})$ \\
\hline
\end{tabular}

* Not Significant

The mean plasma zinc concentrations in Subgroup B-I \& BII were $63.85 \pm 12.49$ and $65.18 \pm 18.48 \mu \mathrm{g} / \mathrm{dl}$ respectively. The mean RBC zinc concentrations in Subgroup B-I \& B-II were $70.62 \pm 16.71$ and $67.08 \pm 17.18 \mu \mathrm{g} / \mathrm{g} \mathrm{Hb}$ respectively. Subgroups B-1 \& B-2 did not differ in respect of plasma and RBC zinc concentrations (Table-5). The plasma zinc concentration of Group-A was significantly higher than that of the Subgroup B-1 but RBC zinc concentration of GroupA \& Subgroup B-1 did not differ (Table -IV). The plasma zinc concentration of Group-A was significantly higher than that of the Subgroup B-2 but RBC zinc concentration of Group-A \& Subgroup B-2 did not differ (Table -V).

Table-5: Comparison of plasma and RBC Zinc concentrations between subgroup of cases.

\begin{tabular}{cccc}
\hline Zinc levels & $\begin{array}{c}\text { Subgroup Bl } \\
\text { Mean } \pm \text { SD }\end{array}$ & $\begin{array}{c}\text { Subgroup Bll } \\
\text { Mean } \pm \text { SD }\end{array}$ & $\begin{array}{c}\text { Level of } \\
\text { significance(p) }\end{array}$ \\
\hline Plasma $(\mu \mathrm{g} / \mathrm{dl})$ & $63.85 \pm 12.49$ & $65.18 \pm 18.48$ & $0.05(\mathrm{NS})$ \\
$\mathrm{RBC}(\mu \mathrm{g} / \mathrm{dl})$ & $70.62 \pm 16.71$ & $67.08 \pm 17.18$ & $0.05(\mathrm{NS})$ \\
\hline
\end{tabular}

* Not Significant
In Group-A plasma total protein, plasma albumin, $\mathrm{RBC}$ lysate protein, plasma glucose, and blood hemoglobin levels were $5.47 \pm 0.65 \mathrm{~g} / \mathrm{dl}, 4.60 \pm 0.21 \mathrm{~g} / \mathrm{dl}, 19.24 \pm 2.47$ $\mathrm{g} / \mathrm{dl}, 67.80 \pm 6.11 \mathrm{mg} / \mathrm{dl}$, and $12.55 \pm 0.82 \mathrm{~g} / \mathrm{dl}$ respectively $\&$ those in Group-B were $4.68 \pm 0.50 \mathrm{~g} / \mathrm{dl}, 3.20 \pm 0.24 \mathrm{~g} / \mathrm{dl}$, $18.96 \pm 1.25 \mathrm{~g} / \mathrm{dl}, 76.27 \pm 18.31 \mathrm{mg} / \mathrm{dl}$, and $11.25 \pm 0.98$ $\mathrm{g} / \mathrm{dl}$ respectively. Plasma protein, plasma albumin \& blood hemoglobin levels were found significantly higher in Group-A (Control) compared to Group-B (Cases) but the plasma glucose and $\mathrm{RBC}$ lysate protein concentrations found to show no significant difference between the groups. Plasma total protein, plasma albumin, RBC lysate protein, plasma glucose and blood hemoglobin levels in Subgroup B-1 were $4.81 \pm 0.48 \mathrm{~g} / \mathrm{dl}, 3.22 \pm 0.16 \mathrm{~g} / \mathrm{dl}, 18.96 \pm 1.31$ $\mathrm{g} / \mathrm{dl}, 75.00 \pm 20.87 \mathrm{mg} / \mathrm{dl}, 11.23 \pm 1.16 \mathrm{~g} / \mathrm{dl}$ and those in Subgroup B-2 were $4.47 \pm 0.31 \mathrm{~g} / \mathrm{dl}, 3.19 \pm 0.20 \mathrm{~g} / \mathrm{dl}, 18.97$ $\pm 1.10 \mathrm{~g} / \mathrm{dl}, 78.00 \pm 13.81 \mathrm{mg} / \mathrm{dl}, 11.18 \pm 0.59 \mathrm{~g} / \mathrm{dl}$ respectively. In comparison of these biochemical parameters Subgroup B-1 \& B-2 found to be same. Maternal plasma zinc \& RBC zinc concentrations found to show no correlation with the birth weight of their babies.

Table-6: Comparison of other biochemical parameters between control (Group - A) and cases (Group - B)

\begin{tabular}{lccc}
\hline Biochemical parameter & $\begin{array}{c}\text { Subgroup Bl } \\
\text { Mean } \pm \text { SD }\end{array}$ & $\begin{array}{c}\text { Subgroup Bll } \\
\text { Mean } \pm \text { SD }\end{array}$ & p Value \\
\hline Plasma protein(g/dl) & $4.81 \pm 0.48$ & $4.47 \pm 0.31$ & NS \\
Plasma albumin(g/dl) & $3.22 \pm 0.16$ & $3.19 \pm 0.20$ & NS \\
RBC lysate protein & $18.96 \pm 1.31$ & $18.97 \pm 1.10$ & NS \\
Plasma glucose $(\mathrm{mg} / \mathrm{dl})$ & $75.0 \pm 20.9$ & $78.0 \pm 13.8$ & $\mathrm{NS}$ \\
Hb level $(\mathrm{g} / \mathrm{dl})$ & $11.23 \pm 1.16$ & $11.18 \pm 0.59$ & $\mathrm{NS}$ \\
\hline
\end{tabular}

* Not Significant

\section{Discussion}

In this present study, mean plasma zinc concentrations in non-pregnant women and pregnant women were $90.10 \pm$ $13.96 \mu \mathrm{g} / \mathrm{dl} \& 64.54 \pm 16.22 \mu \mathrm{g} / \mathrm{dl}$ with the range of $53.71-115.30 \mu \mathrm{g} / \mathrm{dl}$ and $44.54-88.70 \mu \mathrm{g} / \mathrm{dl}$ respectively. The mean plasma zinc levels in the pregnant mothers found significantly lower than that in the non-pregnant control women. Same phenomenon observed in many other studies around the world ${ }^{6-10}$. In theses studies, 15$35 \%$ lowering of plasma zinc level in pregnancy compared with control observed are well in agreement with our finding showing about $20 \%$ decline. The fall in plasma zinc concentration during pregnancy, in part, occurs due to physiological hemodilution accomplished via expansion of plasma volume \& maternal-fetal transfer of zinc, to meet the fetal demand ${ }^{11-13}$. In addition to fetal accumulation, zinc is also deposited in placenta \& amniotic fluid, leading to the lowering of maternal plasma zinc ${ }^{2}$. Moreover urinary zinc excretion paradoxically increases in late pregnancy, when absolute quantity of zinc required by the fetus is the greatest ${ }^{13}$.

It is speculated that during pregnancy, the binding affinity of zinc to carrier protein is reduced, which might facilitates maternal-fetal transfer of zinc as well as the pregnancy induced increased urinary zinc excretion ${ }^{6}$. 
Mean \pm SD RBC zinc concentration found in Group-A (Control) and Group-B (Cases) were $66.92 \pm 12.74 \mu \mathrm{g} / \mathrm{g}$ $\mathrm{Hb} \& 68.85 \pm 16.82 \mu \mathrm{g} / \mathrm{g} \mathrm{Hb}$ with the range of $52.70-$ $107.00 \mu \mathrm{g} / \mathrm{g} \mathrm{Hb}$ and $43.30-91.30 \mu \mathrm{g} / \mathrm{g} \mathrm{Hb}$ respectively, without any significant difference between the groups. These results are consistent with other study ${ }^{3}$.

The concentration of RBC zinc did not differ between pregnant and non-pregnant state because normal pregnancy do not induce zinc deficiency ${ }^{6}$. Since the RBC zinc concentration is considered as a relatively good index of zinc status so our finding apparently indicates that there was no zinc deficiency in our study cases.

Compared to control, cases subgroups B-1 (Giving birth to normal birth weight babies) \& B-2 (Giving birth to low birth weight babies) found to show significantly reduced plasma zinc concentration but no difference with respect to $\mathrm{RBC}$ zinc concentration. Cases subgroups (B-1 \& B-2) also showed no difference with respect to plasma \& RBC zinc concentrations when values were compared between the cases subgroups.

The present study findings are in agreement with many other studies?. Probably the mothers of both normal \& low birth weight babies have had adequate supplementation of zinc and other nutritional supports for the growth and development of their fetus but the inadequate fetal utilization of nutrients due to some reasons might be responsible for fetal growth retardation (LBW) in cases Subgroup B-2.

Plasma total protein, plasma albumin \& blood hemoglobin levels were found significantly reduced in Cases (GroupB) compared to Control (Group-A) but the plasma glucose and $\mathrm{RBC}$ lysate protein concentrations found to show no significant difference between the groups. As revealed and proposed by other studies these changes found in pregnancy are well within the physiological limits ${ }^{4-6}$. Blood volume increases about $25 \%$ during pregnancy and at the same time plasma total protein, plasma albumin and blood hemoglobin decreases. With respect to plasma total protein, plasma albumin, RBC lysate protein, plasma glucose and blood hemoglobin levels Cases Subgroups B-1 \& B-2 found to be same. So this finding apparently indicates that there was no malnutrition in this study cases.

Maternal plasma and RBC zinc concentrations found to show no correlation with the birth weight of their babies. The relationship between maternal plasma \& RBC zinc concentrations and birth weight of their babies is not completely clear ${ }^{8}$. A case control study involving 20 non- pregnant (Control) and 40 pregnant (Cases) women was designed in the department of Biochemistry, Dhaka medical college, Dhaka to find out the relationship between maternal zinc status and fetal outcome. Mean plasma zinc concentrations in pregnant cases found to be significantly lower than that of the non-pregnant Control. But RBC zinc concentrations of control and cases did not differ. Maternal plasma zinc and RBC zinc concentrations found to show no correlation with the birth weight of their babies.

\section{Conclusion}

This study shows no relationship between maternal zinc status and birth weight of their babies. Zinc supplementation during pregnancy improves neurobehavioral development of fetus. Thus antenatal zinc supplementation may have an important role to play in improving maternal, fetal \& infant's well being if not affecting fetal growth.

\section{References}

1. Hallberg L, Sandström B, Aggett PJ. Iron, zinc and other trace elements. In: Human nutrition and dietetics, 10th edn. Garrow JS, James WPT, Ralph A, Churchill Livingstone, Edinburgh 2000; pp 192-208

2. Swanson CA, King JC. Zinc and pregnancy outcome. Am J Clin Nutr 1987;46:763-771

3. Apgar J. Zinc and reproduction: an update. J Nutr Biochem. 1992; 3 : 266-278

4. Hurley LS, Swenerton H. Congenital malformations resulting from zinc deficiency in rats. Soc Exp Biol Med. 1966; 123: 692-696

5. King JC. Determinants of maternal zinc status during pregnancy. Am J Clin Nutr. 2000; 71(Suppl): 1334S-1343S

6. Gibson RS, Vanderkooy PDS,MacDonald AC, Goldman A, Ryan BA, Berry M. A growth-limiting, mild zinc-deficiency syndrome in some Southern Ontario boys with low height percentiles. Am J Clin Nutr. 1989; 49: 1266-1273

7. Catalanotto FA. The trace metal zinc and taste. Am J Clin Nutr 1978; 31: 1098-1103

8. Golden MHN, Golden BE. Effect of zinc supplementation on the dietary intake, rate of weight gain and energy cost of tissue deposition in children recovering from severe malnutrition. Am J Clin Nutr 1981; 34: 900-908

9. Goel R, Misra PK. Study of plasma zinc in protein energy malnutrition. Indian Pediatr. 1980; XVII: 863-867

10. Beach RS, Gershwin ME, Hurley LS. Growth and development in postnatally zinc-deprived mice. J Nutr. 1980; 110: 201-211

11. Osendrap SJM, Van Raaij JMA, Darmstadt GL, Baqui AH, Hautvast JGAJ, Fuchs GJ. Zinc supplementation during pregnancy and effects on growth and morbidity in low birthweight infants: a randomized placebo controlled trial. Lancet 2001; 357: 1080-108

12. Gupta BD, Miglani N. Zinc in Indian childhood cirrhosis I. Assessment of serum zinc. Indian Pediatr. 1977; XIV(3):175-179

13. Week JC, Keen CL,Vogler JB, Golub MS, Hurley LS, Hendrickx AG, Gershwin ME. Long-term marginal zinc deprivation in rhesus monkeys. IV Effects on skeletal growth and mineralization. Am J Clin Nutr 1988; 47: 889-895 